\title{
DNA FINGERPRINTING TO IDENTIFY SOME FABA BEAN (Vicia faba L.) VARIETIES \\ El-Danasoury, M. M. ${ }^{1}$; A. E. El-Ghubashy'; H. Yossif ${ }^{1}$ and R. T. Behairy ${ }^{2}$ \\ 1- Department of Biochemistry, Faculty of Agric., Al-Azhar University. \\ 2- Seed Tech. Res. Sec., Field Crops Res. Institute, A.R.C.
}

\begin{abstract}
The objectives of this study were to identify ten faba bean (Vicia faba L.) varieties using DNA fingerprinting detected by Random Amplified Polymorphic DNA (RAPD). The RAPD analysis for the ten faba bean varieties utilizing five random 10mer primers was showed that the number of bands for each primer ranged from one $(\mathrm{A} 12)$ to $12(\mathrm{~B} 10)$. The molecular size of the bands for each primer ranged from 85 $\mathrm{bp}(\mathrm{B} 01)$ to $10744 \mathrm{bp}$.(B 20).Primer(A12)gave a maximum of 7 bands ranged from 260 to $4710 \mathrm{bp}$. One specific band was exhibited for $\mathrm{G} .717$ faba bean variety with 2901 bp. This band could be used to characterize this variety from the others. Primer (A07) exhibited 5 amplification product at the molecular size ranged between 510 and 4385 bp.A specific band was exhibited for Y.S. variety of $4385 \mathrm{bp}$, this band could be used to distinguish this variety. Primer (B 20) gave a maximum 16 bands ranged from 275 to $10744 \mathrm{bp}$. Some varieties had some specific bands which could be used to identify them among the others. For instance, Nu.1 variety contained three specific bands of $2153 \mathrm{bp}, 1015 \mathrm{bp}$ and $820 \mathrm{bp}$. Primer(B10)gave amaximum12 bands ranging from $460 \mathrm{bp}$ to $3635 \mathrm{bp}$. The fragment with the molecular size of 1850 was present in all varieties except for Y.S. Primer(B01) gave a maximum of 15 bands ranged between 85 and 8080 bp. Variety Sa.2 could be distinguish from the others varieties by the presence of unique fragments at $8080 \mathrm{bp}$. Also, two specific bands which were found in Y.S. variety with $4985 \mathrm{bp}$ and $2445 \mathrm{bp}$. These could be used to characterize and identify this variety among others (as a positive specific marker)
\end{abstract}

\section{INTRODUCTION}

Faba bean (Vicia faba L.) is one of the most important winter field crops in Egypt, its dry seeds are important source of protein for food and feed. World cultivated area of faba bean was 6,364 million fed. and the production was 4,343 million ton $(F A O, 2005)$.Cultivated area of faba bean in Egypt is about 198000 fed in 2005, with an average dry seed production of 9.10 ardab per fed. ( 1 ardab $=155 \mathrm{~kg}$ ). This production covers $67 \%$ from consumption (Agriculture Economics, 2005). Faba bean is considered as an important component of people diet in developing countries. The been is consumed in the form of immature tender green pods, green mature seeds or as dry seeds after slow boiling cooking (medames). In Egypt, Faba bean seeds are among the major nutritional source of plant proteins.

One of the recent advances in genetic purity testing is the Polymerase Chain Reaction (PCR) technique, which is known by random amplification of polymorphic DNA (RAPD). This technique is used for several plant systems and are expected to play a very important role in the future of plant breeding programs. The revolution of polymerase chain reaction (PCR) technique has been initiated as novel genetic assay based on selective DNA 
amplification (Saiki et al.1983). Randomly amplified polymorphic DNA(RAPD) has been the most wide spread DNA analysis during the last decade. This analysis is more amenable to automation than conventional analysis. It is simple to perform and preferable in experiments when large number of individuals are determined in a few genetic, it requires only a small amount of DNA and provides a quick method for developing genetic maps. Targeting genetic markers has been explored in Vicia genus mainly at the interspecific level (Van de ven et al. 1993).

Torres et al. (1993) studied linkage among isozyme, RFLP and RAPD markers in Vicia faba. Segregation in allozymes and DNA polymorphisms were used to construct a preliminary linkage map for faba bean. They revealed linkage relationships of nine isozymes, one RFLP marker and 43 RAPD markers of Vicia faba as a first step towards the development of complete genetic map for this species.

The RAPD markers are easily generated by PCR, useful for the rapid generation of phylogenetic relationship data and have been used for bulked sergeants analysis in cereals and other numerous plant species. However, they are non-reproducible due to the low annealing temperature conditions required for the PCR reaction. They do not usually show co-dominance and, therefore, heterozygote can not generally be distinguished from homozygotes of one class (Rafalski and Tingey, 1993; Jones et al. 1997)

Galasso et al., (1997) applied RAPD in fingerprinting of 27 accessions including the two Vicia benghalensis biotypes ( $A$ and $B$ ). Accessions belonging to be biotype $A$ showed a high degree of genetic similarity, while the opposite was true for the accessions of biotype B.

Haider et al. (2001) carried out a study to determine the genetic diversity between faba bean and its related Vicia Species (V.sativa, V. villosa, V.monantha, V.narbonensis and V.cinerea, in addition to V.faba). Variability on the DNA level was investigated through RAPD-PCR analysis which indicated clear differences among different Vicia species and similarities within the same species. The authors concluded that V.monantha and $V$.villosa are most closely related to V.cinerea. Their results distincted completely V.faba and V.narbonensis. The molecular markers between $V$.faba and other wild species indicated that none of the latter can be considered as the wild progenitor of V.faba.

Gadalla (2004) mentioned that the RAPD-PCR was used to analyze the genetic diversity of ten faba bean cultivars and to asses their genetic relationships using similarity index and dendogram tree.Ten random primers were used to determine RAPD polymorphism. All the ten primers successfully amplified DNA fragments for all genotypes. Primers produced band numbers ranging from 4 to 19 fragments across cultivars.

This investigation was carried out to identify ten Faba bean (Vicia faba L.) varieties using DNA fingerprinting detected by Random Amplified Polymorphic DNA (RAPD) 


\section{MATERIALS AND METHODS}

\section{A- Seed samples.}

Seeds of ten varieties of faba bean Vicia faba $L$. were used in this investigation namely, Sakha 1(Sa.1), Sakha 2(Sa.2), Nubaria 1(Nu.1), Masr 1(M.1), Giza 3 Im(G.3lm), Giza 461(G.461), Giza 643(G.643), Giza 717(G.717), Giza 843(G.843) and Y.Elsedik(Y.S.). Seed samples under study were obtained from the Leguminous Crops Department Research (LCDR), Field Crops Research Institute, Agricultural Research Center, Ministry of Agriculture, Giza, Egypt.

\section{B- DNA Molecular studies.}

The RAPD markers assays are based on the PCR amplification of random locations in the plant genome. The DNA amplification protocol was performed as described by Williams et al. (1990) with some modifications. The DNA isolation from plant tissues was conducted using DNneasy Plant Mini kit (QIAGEN Hilden, Germany). The RAPD-PCR reactions were conducted using 5 arbitrary 10-mer primers. Their names and sequences are shown in Table (1).

Table (1): Primer names and sequences in 5 to 3 direction

\begin{tabular}{|l|c|}
\hline \multicolumn{1}{|c|}{ Primer Name } & Sequence (5 to 3 ) \\
\hline P1(A12) & TCGGCGATAG \\
\hline P2(A07) & GAAACGGGTG \\
\hline P3(B20) & GGACCCTTAC \\
\hline P4(B10) & CTGCTGGGAC \\
\hline P5(B01) & GTTTCGCTCC \\
\hline
\end{tabular}

The reaction conditions according to Williams et al. (1990) were optimized and mixtures ( $30 \mu \mathrm{l}$ total volume) consisted of the following were used: dNTPs (2.5 Mm) $0.2 \mathrm{mM}, \mathrm{MgCl} 2(25 \mathrm{Mm}) 1.5 \mathrm{~m} \mathrm{M}, 10 \times$ buffer $3.0 \mu \mathrm{l}$, Primer $(10 \mu \mathrm{M}) 0.2 \mu \mathrm{M}$, TemplateDNA $(50 \mathrm{NG} / \mu \mathrm{L}) 2.0 \mu \mathrm{L}$, Taq $(5 \mathrm{u} / \mu \mathrm{l}) 0.3 \mu \mathrm{l}$, D H2O up to $30 \mu \mathrm{l}$.Amplification was carried out in a PTC-200 thermal cycles (MJ Research, Watertown, USA) programmed for 40 cycles as follows : 94 ${ }^{\circ} \mathrm{C} / 4 \mathrm{~min}$ (1 cycle) ; $94{ }^{\circ} \mathrm{C} / 30 \mathrm{sec}, 36{ }^{\circ} \mathrm{C} / 1 \mathrm{~min}, 72 \circ \mathrm{C} / 2 \mathrm{~min}$ (40 cycles); 72 $\circ \mathrm{C} / 10 \mathrm{~min}$ (1cycle) and $4 \circ \mathrm{C}$ (infinitive) .

\section{C- Data analysis.}

The similarity matrices were done using gel works advanced software UVP-England Program. The relationships among varieties as revealed by dendograms were done using SPSS Windows (version 10) Program.

\section{RESULTS AND DISCUSSION}

In the present study, five random primers were used to differentiate through RAPD analysis between the ten faba bean varieties as recorded in Tables (2 to 6).Polymorphism results from DNA sequences variation at primer binding sites or from length differences between primer binding sites. This polymorphism scored as the presence or absence of the amplified fragments in the different samples, therefore, RAPD are considered as dominant markers. 


\section{1- Primer A 12.}

Results presented in table (2) and figure (1) showed primer A12.It can be seen that the total number of bands in all varieties were seven bands ranged from $260 \mathrm{bp}$ to $4710 \mathrm{bp}$. The number of bands ranged from one band in two varieties (M.1 and G.3 Im.) to six bands in Sa.2 variety. Band which has about $1860 \mathrm{bp}$ is found in all varieties except G. 3 and Nu.1. Meanwhile, band with 4710 bp is present only in varieties Sa.1 and Sa.2. Single specific band with molecular weight of $1290 \mathrm{bp}$ is found in G.717 faba bean variety. This band could be used to characterize such variety from the others and can be considered as a positive specific marker. No common band is detected for all the studied varieties .

Table (2): DNA polymorphism using randomly amplified polymorphic DNA with primer A 12.

\begin{tabular}{|c|c|c|c|c|c|c|c|c|c|c|c|}
\hline $\begin{array}{c}\text { Band } \\
\text { NO. }\end{array}$ & MW. & M.1 & G.643 & $\begin{array}{c}\text { G.3 } \\
\text { Im }\end{array}$ & G.717 & G.461 & G.843 & Y.S. & Nu.1 & Sa.1 & Sa.2 \\
\hline $\mathbf{1}$ & 4710 & - & - & - & - & - & - & - & - & + & + \\
\hline $\mathbf{2}$ & 3610 & - & + & - & + & + & - & + & + & + & + \\
\hline $\mathbf{3}$ & 2360 & - & - & + & - & - & + & - & - & + & + \\
\hline $\mathbf{4}$ & 1860 & + & + & - & + & + & + & + & - & + & + \\
\hline $\mathbf{5}$ & 1290 & - & - & - & + & - & - & - & - & - & - \\
\hline $\mathbf{6}$ & 925 & - & + & - & + & + & - & + & + & + & + \\
\hline 7 & 260 & - & + & - & - & + & - & + & + & - & + \\
\hline
\end{tabular}

(+) Band presence

(-) Band absence

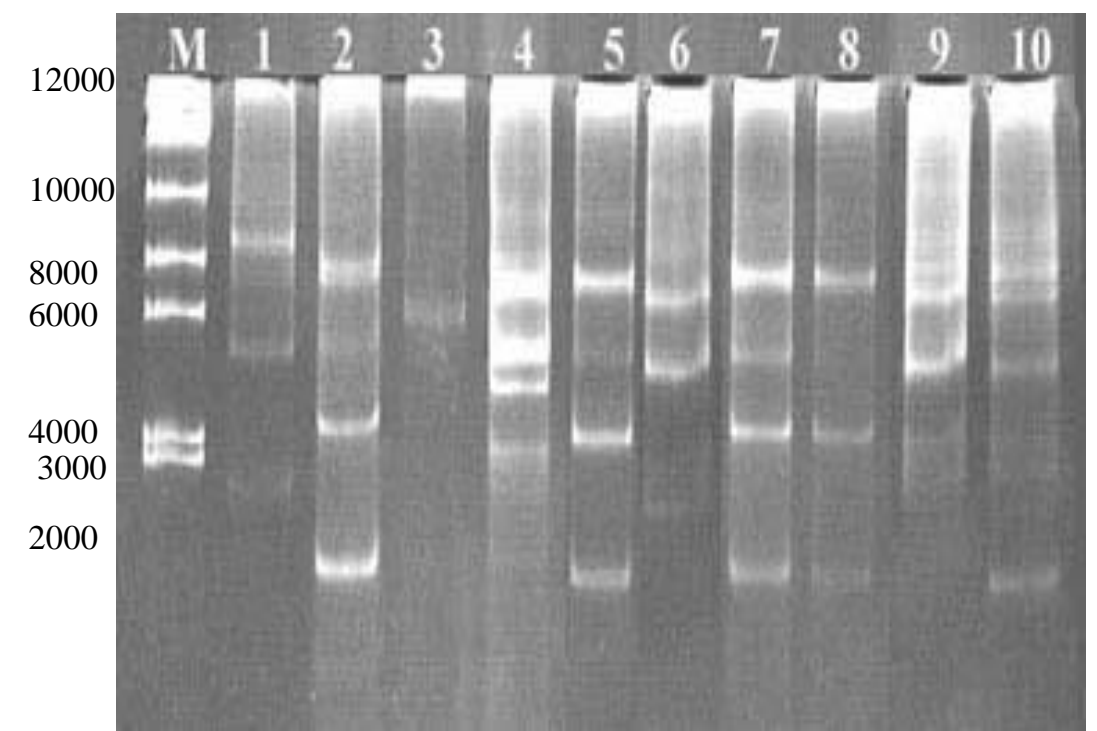

Fig. (1): DNA polymorphism of ten varieties using randomly amplified polymorphic DNA with primer OP- A12. 


\section{2- Primer A 07.}

The results of primer A07 are shown in Table (3) and figure (2) .Results indicated that the maximum of five bands ranged from $510 \mathrm{bp}$ to $4385 \mathrm{bp}$ were obtained. The number of bands ranged from two bands in two varieties G.3 Im. and Nu.1 to four bands in four varieties G.461, G.843, Y.S. and Sa.1. Single common band at $2035 \mathrm{bp}$ is found in all the studied varieties. Other specific band is exhibited for Y.S. faba bean variety with $4385 \mathrm{bp}$. This band could be used to distinguish this variety among the others. The band which has about $1295 \mathrm{bp}$ is found in all varieties except G.643. So it can be considered as a negative specific marker.

Table (3): DNA polymorphism using randomly amplified polymorphic DNA with primer A 07.

\begin{tabular}{|c|c|c|c|c|c|c|c|c|c|c|c|}
\hline $\begin{array}{c}\text { Band } \\
\text { NO. }\end{array}$ & MW. & M.1 & G.643 & $\begin{array}{c}\text { G.3 } \\
\text { Im }\end{array}$ & G.717 & G.461 & G.843 & Y.S. & Nu.1 & Sa.1 & Sa.2 \\
\hline $\mathbf{1}$ & 4385 & - & - & - & - & - & - & + & - & - & - \\
\hline $\mathbf{2}$ & 3945 & + & + & - & + & + & + & + & - & + & - \\
\hline 3 & 2035 & + & + & + & + & + & + & + & + & + & + \\
\hline $\mathbf{4}$ & 1295 & + & - & + & + & + & + & + & + & + & + \\
\hline $\mathbf{5}$ & 510 & - & + & - & - & + & + & - & - & + & + \\
\hline
\end{tabular}

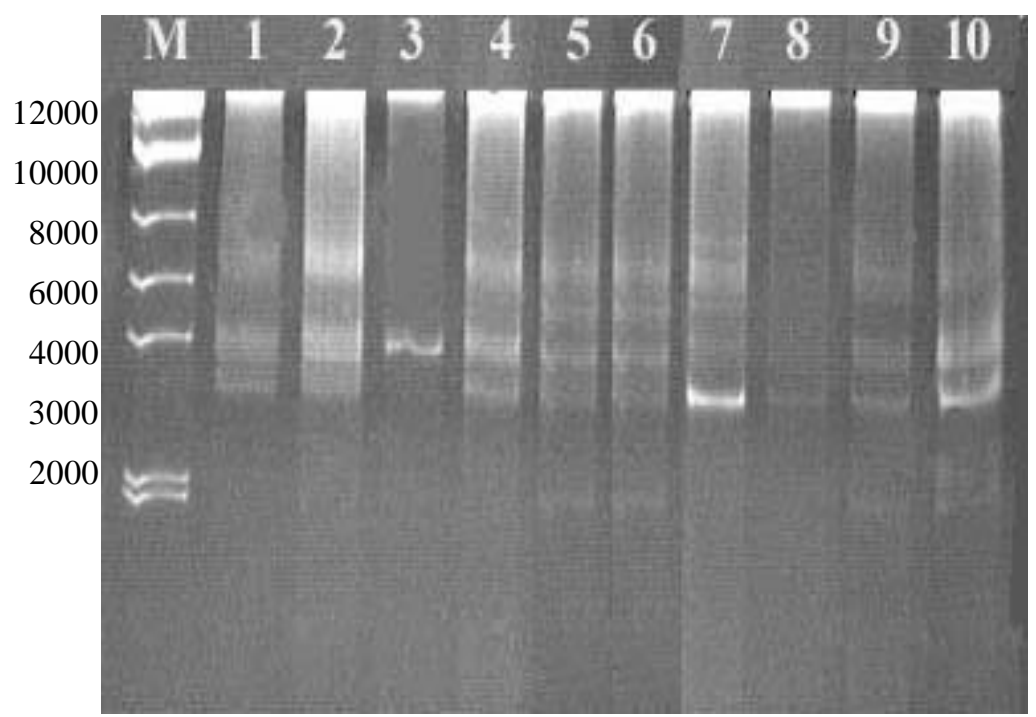

Fig. (2): DNA polymorphism of ten varieties using randomly amplified polymorphic DNA with primer OP- A07.

\section{3- Primer B 20.}

Table (4) and figure (3) show data of primer B 20. This primer produced a total of 16 bands ranging from $275 \mathrm{bp}$ to $10744 \mathrm{bp}$. Two bands are shown in three varieties (M.1, G.843 and Sa.2) and ten bands in Y.S. variety. There is no common band for all faba bean varieties under investigation. Some 
varieties have some specific bands which can be used to distinguish them among the others. For instance, five specific bands for variety Y.S. with 10744 bp, 3360 bp, 1160 bp, 390 bp and 275 bp. Similarly Nu.1 variety contained three specific bands with $2153 \mathrm{bp}, 1015 \mathrm{bp}$ and $820 \mathrm{bp}$. Whereas, band with 1640 bp is present only in varieties G.643 and G.461. Bands with $660 \mathrm{bp}$ and $535 \mathrm{bp}$ are present only in three varieties (G.843, Y.S. and Sa.1), therefore they can be considered as a positive specific marker for these varieties.

Table (4): DNA polymorphism using randomly amplified polymorphic DNA with primer B 20.

\begin{tabular}{|c|c|c|c|c|c|c|c|c|c|c|c|}
\hline $\begin{array}{c}\text { Band } \\
\text { NO. }\end{array}$ & MW. & $\begin{array}{c}M . \\
1\end{array}$ & $\begin{array}{c}\text { G. } \\
643\end{array}$ & $\begin{array}{l}\text { G.3 } \\
\text { Im }\end{array}$ & $\begin{array}{c}\text { G. } \\
717\end{array}$ & $\begin{array}{c}\text { G. } \\
461\end{array}$ & $\begin{array}{c}\text { G. } \\
843\end{array}$ & Y.S. & $\begin{array}{c}\text { Nu. } \\
1\end{array}$ & $\begin{array}{c}\text { Sa. } \\
1\end{array}$ & $\begin{array}{c}\text { Sa. } \\
2\end{array}$ \\
\hline 1 & 10744 & - & - & - & - & - & - & + & - & - & - \\
\hline 2 & 9490 & - & + & - & + & - & - & + & + & + & - \\
\hline 3 & 6715 & + & + & + & + & + & - & - & + & + & - \\
\hline 4 & 5145 & + & + & + & + & + & - & - & - & - & - \\
\hline 5 & 3640 & - & + & + & + & + & - & + & + & + & + \\
\hline 6 & 3360 & - & - & - & - & - & - & + & - & - & - \\
\hline 7 & 2790 & - & - & + & + & - & - & + & - & - & + \\
\hline 8 & 2135 & - & - & - & - & - & - & - & + & - & - \\
\hline 9 & 1640 & - & + & - & - & + & - & - & - & - & - \\
\hline 10 & 1160 & - & - & - & - & - & - & + & - & - & - \\
\hline 11 & 1015 & - & - & - & - & - & - & - & + & - & - \\
\hline 12 & 820 & - & - & - & - & - & - & - & + & - & - \\
\hline 13 & 660 & - & - & - & - & - & + & + & - & + & - \\
\hline 14 & 535 & - & - & - & - & - & + & + & - & + & - \\
\hline 15 & 390 & - & - & - & - & - & - & + & - & - & - \\
\hline 16 & 275 & - & - & - & - & - & - & + & - & - & - \\
\hline \multicolumn{2}{|c|}{ Total of bands } & 2 & 5 & 4 & 5 & 4 & 2 & 10 & 6 & 5 & 2 \\
\hline
\end{tabular}

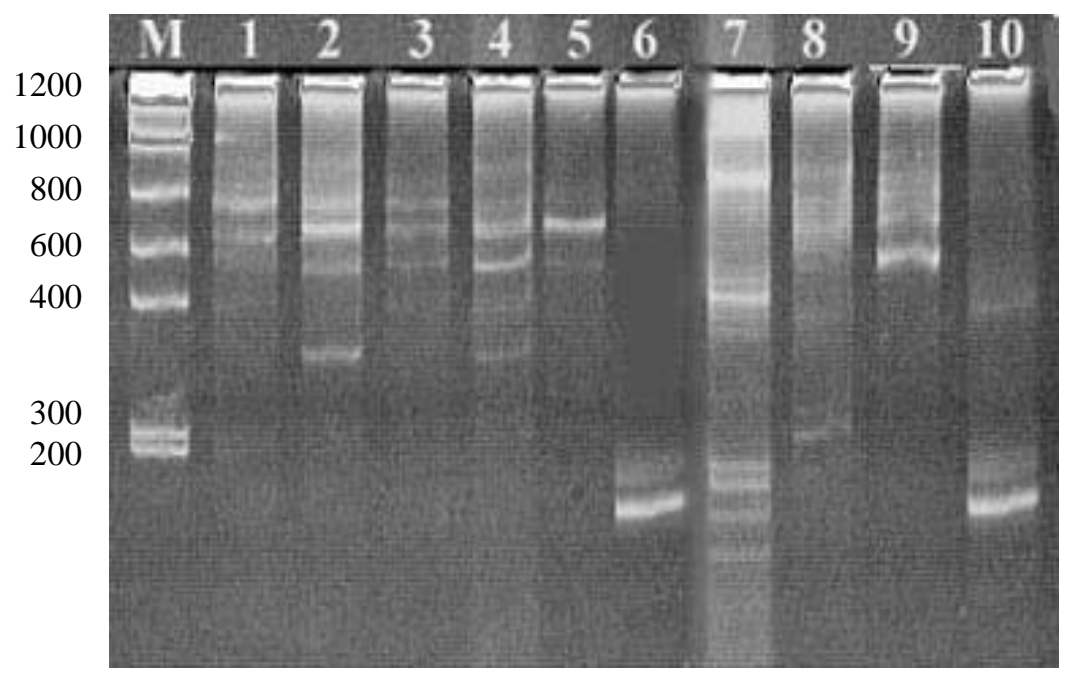

Fig.(3): DNA polymorphism of ten varieties using randomly amplified polymorphic DNA with primer OP- B20. 


\section{4- Primer B 10.}

Data of primer B 10 are recorded in Table (5) and figure (4) showed a maximum of 12 bands ranged between $460 \mathrm{bp}$ and $3635 \mathrm{bp}$., seven bands in G.3 Im. variety to twelve bands in G.461 and Nu.1 varieties. Six common bands were observed in all varieties with 3635 bp, $2695 \mathrm{bp}, 1440 \mathrm{bp}, 1265$ $\mathrm{bp}, 800 \mathrm{bp}$ and $605 \mathrm{bp}$. Meanwhile, the fragment with the molecular size of 1850 is present in all varieties except Y.S. So it can be considered as specific negative marker. Also, bands with $1080 \mathrm{bp}$ and $940 \mathrm{bp}$ are absent only in variety G.3 Im. While, bands with $460 \mathrm{bp}$ is present only in the three varieties, G.461, Y.S. and Nu.1 which could be used as a positive specific marker.

Table (5): DNA polymorphism using randomly amplified polymorphic DNA with primer B 10.

\begin{tabular}{|c|c|c|c|c|c|c|c|c|c|c|c|}
\hline $\begin{array}{c}\text { Band } \\
\text { NO. }\end{array}$ & MW. & $\begin{array}{c}\text { M. } \\
\mathbf{1}\end{array}$ & $\begin{array}{c}\text { G. } \\
\mathbf{6 4 3}\end{array}$ & $\begin{array}{c}\text { G.3 } \\
\text { Im }\end{array}$ & $\begin{array}{c}\text { G. } \\
\mathbf{7 1 7}\end{array}$ & $\begin{array}{c}\text { G. } \\
\mathbf{4 6 1}\end{array}$ & $\begin{array}{c}\text { G. } \\
\mathbf{8 4 3}\end{array}$ & $\mathbf{Y . S .}$ & $\begin{array}{c}\text { Nu. } \\
\mathbf{1}\end{array}$ & $\begin{array}{c}\text { Sa. } \\
\mathbf{1}\end{array}$ & $\begin{array}{c}\text { Sa. } \\
\mathbf{2}\end{array}$ \\
\hline $\mathbf{1}$ & 3635 & + & + & + & + & + & + & + & + & + & + \\
\hline $\mathbf{2}$ & 2695 & + & + & + & + & + & + & + & + & + & + \\
\hline $\mathbf{3}$ & 2540 & - & - & - & + & + & + & + & + & + & + \\
\hline $\mathbf{4}$ & 1850 & + & + & + & + & + & + & - & + & + & + \\
\hline $\mathbf{5}$ & 1440 & + & + & + & + & + & + & + & + & + & + \\
\hline $\mathbf{6}$ & 1265 & + & + & + & + & + & + & + & + & + & + \\
\hline $\mathbf{7}$ & 1080 & + & + & - & + & + & + & + & + & + & + \\
\hline $\mathbf{8}$ & 940 & + & + & - & + & + & + & + & + & + & + \\
\hline $\mathbf{9}$ & 800 & + & + & + & + & + & + & + & + & + & + \\
\hline $\mathbf{1 0}$ & 605 & + & + & + & + & + & + & + & + & + & + \\
\hline $\mathbf{1 1}$ & 515 & - & - & - & - & + & - & + & + & + & + \\
\hline $\mathbf{1 2}$ & 460 & - & - & - & - & + & - & + & + & - & - \\
\hline
\end{tabular}

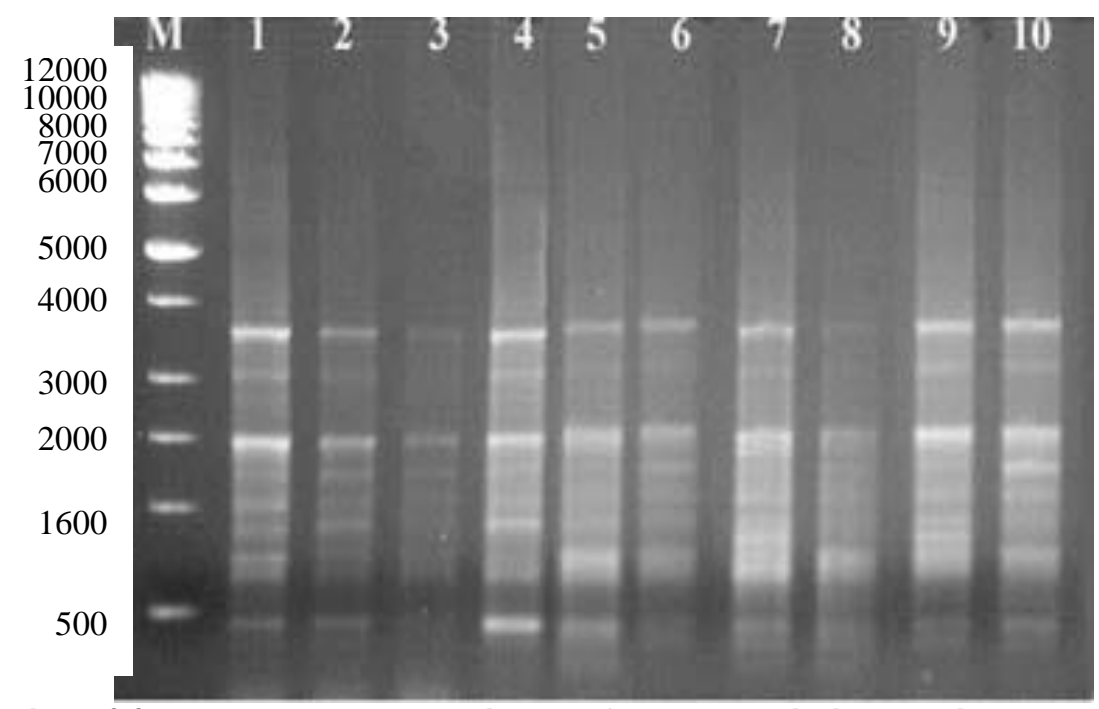

Fig. (4): DNA polymorphism of ten varieties using randomly amplified polymorphic DNA with primer B10. 


\section{5- Primer B 01}

Table (6) and figure (5) show data of primer B 01 . This primer produce a total of 15 bands ranging from $85 \mathrm{bp}$ to $8080 \mathrm{bp}$. The number of bands ranged from three bands in variety $\mathrm{G} .3 \mathrm{Im}$. to nine bands in variety Y.S. .However, variety Sa.2 can be distinguished by the presence of unique fragment at $8080 \mathrm{bp}$. Also, two specific bands were recorded for Y.S. variety with 4985 bp and 2445 bp.

Table (6): DNA polymorphism using randomly amplified polymorphic DNA with primer B 01.

\begin{tabular}{|c|c|c|c|c|c|c|c|c|c|c|c|}
\hline $\begin{array}{c}\text { Band } \\
\text { NO. }\end{array}$ & MW. & $\begin{array}{c}M . \\
1\end{array}$ & $\begin{array}{c}\text { G. } \\
643\end{array}$ & $\begin{array}{l}\text { G.3 } \\
\text { Im }\end{array}$ & $\begin{array}{c}\text { G. } \\
717\end{array}$ & $\begin{array}{c}\text { G. } \\
461\end{array}$ & $\begin{array}{c}\text { G. } \\
843\end{array}$ & Y.S. & $\begin{array}{c}\text { Nu. } \\
1\end{array}$ & $\begin{array}{c}\text { Sa. } \\
1\end{array}$ & $\begin{array}{c}\text { Sa. } \\
2\end{array}$ \\
\hline 1 & 8080 & - & - & - & - & - & - & - & - & - & + \\
\hline 2 & 7540 & - & + & - & - & - & - & - & + & - & - \\
\hline 3 & 5725 & - & - & - & + & - & - & - & + & - & - \\
\hline 4 & 4985 & - & - & - & - & - & - & + & - & - & - \\
\hline 5 & 4150 & - & + & - & - & - & - & - & - & - & + \\
\hline 6 & 2740 & - & + & + & + & + & + & + & + & + & + \\
\hline 7 & 2445 & - & - & - & - & - & - & + & - & - & - \\
\hline 8 & 1860 & + & - & - & - & - & - & + & - & - & - \\
\hline 9 & 1200 & + & - & - & - & - & - & - & - & + & - \\
\hline 10 & 890 & + & + & + & + & + & + & + & + & + & + \\
\hline 11 & 690 & + & + & - & - & + & + & + & + & + & + \\
\hline 12 & 480 & + & - & - & - & - & - & + & - & - & + \\
\hline 13 & 235 & - & - & - & + & - & - & + & - & - & - \\
\hline 14 & 205 & + & + & + & + & + & + & - & + & + & + \\
\hline 15 & 85 & + & - & - & 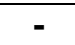 & - & - & + & - & - & - \\
\hline Total of & bands & 7 & 6 & 3 & 5 & 4 & 4 & 9 & 6 & 5 & 7 \\
\hline
\end{tabular}

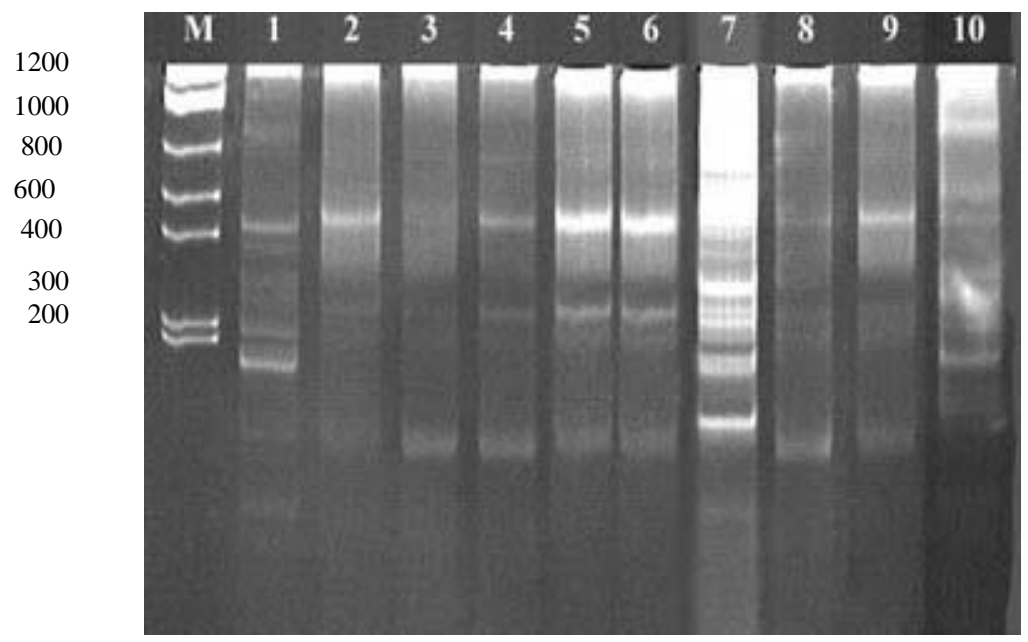

Fig. (5): DNA polymorphism of ten varieties using randomly amplified polymorphic DNA with primer OP- B01. 
These bands can be used to characterize this particular variety from the others (as a positive specific marker). Whereas, the bands as about 2740 bp and $205 \mathrm{bp}$ are found in all varieties except M.1 and Y.S. Also, the fragment with $690 \mathrm{bp}$ is absent only in two varieties G.3 Im. and G.717. This can be considered as negative specific marker. Meanwhile, there is unique common Fragment in rieties at $890 \mathrm{bp}$.

\section{Genetic similarity and cluster analysis:}

The RAPD data developed by all primers of this study were used to estimate the genetic similarity among the ten varieties.

The genetic similarity matrix based on all possible pairs of cultivars ranged from $44 \%$ to $85 \%$ (Table 7 ). The lowest genetic similarity was shown between varieties G.3 and Y.S. (similarity 44\%). While the highest genetic similarity is shown between varieties G.643 and G.461 and varieties G. 641 and Sa.1 (similarity $85 \%$ ). The other in between similarities can be detected from data presented in Table (7).

Table (7): Similarity matrix among ten Faba Bean cultivars based on RAPD analysis. 
EI-Danasoury, M. M. et al.

Figure (6): The genetic distances between the ten faba bean varieties based on RAPD analysis.

The obtained results for RAPD fingerprints of faba bean varieties are along the same line with those of Torres et al. (1993)and Van de Ven et al. (1993) where they found that RAPD technique can be used as a tool for determining the extent of genetic diversity among faba bean for allocating genotypes into different groups. Also, Link et al. (1995) examined three groups of faba bean inbred lines by means of RAPD assay. They concluded that RAPD are useful way for classification of germplasm and identification of divergent heterotic groups in faba bean. In the same respect, Stovic et al. (1996) reported that RAPD can be used as a tool for determining the extent of genetic diversity among $13 \mathrm{~F}_{2}$ families of faba bean for allocating genotypes into different groups. Moreover, Black-Samuelsson et al. (1997) estimated the variation in growth and fecundity traits with RAPD of natural population of Vicia pisiformis plants. When using 11 primers, they found low inter - and intra-population variation in RAPD markers. Haider et al. (2001) studied the genetic diversity between faba bean and its related Vicia Species. Variability on the DNA level was investigated through RAPD-PCR analysis which indicated clear differences among different Vicia species and similarities within the same species. The molecular markers between V.faba and other wild species indicated that none of the latter can be considered as a wild progenitor of V.faba. Also, Gadalla (2004) indicated that RAPD-PCR can be used to analyze the genetic diversity of ten faba bean cultivars to asses their genetic relationships using similarity index and dendogram tree. 


\section{REFERENCES}

Agriculture Economics Bulletin of, Ministry of Agriculture, Egypt (2005)

Black-Samuelsson, S.; Eriksson, G.; Gustafsson, L. and Gustafsson, P. (1997). RAPD and morphological analysis of the rare plant species Vicia pisiformis (fabaceae). Biological Journal of the linnean Society, 103: 325-343.

FAO (2005).FAO state 2005 agriculture data .Agriculture production, crops primary. Food and Agriculture Organization of United Nations

Gadalla, N. M. (2004). Molecular genetic studies on faba bean (Vicia faba L.) in relation to some economic characteristics. M Sc. Thesis, Genetics Dept.Fac. of Agric. Ain shams University

Galasso, I.; Sonnante, G.; Tota, D. G. and Pignone, D. (1997). Comparison of molecular cytogenetic and genetic analysis in accessions of the tow biotypes of Vicia benghalensis. Annals of Botany, 3: 311-317.

Haider, A.S.; Bahieldin, A.; Hassanin, R.; Mahmoud, N. and Madkour, M. (2001). Molecular characterization of some species of genus Vicia. Arab Journal of Biotechnology; 4: 197-206.

Jones, N.; Ougham, H. and Thomas, T. (1997). Markers and Mapping: We are all geneticist now. New Phyto., 137: 165-177.

Link, W.; Dixkens, C.; Singh, M.; Schwall, M. and Melchinger, A.E. (1995). Genetic diversity in European and Mediterranean faba bean germplasm revealed by RAPD markers. Theor.Appl.Geneties, 90:27-32

Rafalski, J.A. and Tingey, S.V. (1993). Genetic diagnostic in plant breeding; RAPD, microsatellits and machines. Genetics, 9: 275-280.

Saiki, R. K.; Gelfond, D. H.; Scharf, S. J.; Higuch, R.; Horn, G. T.; Mullis, K. B. and Erlch, H. A. (1983). Primer directed enzymatic amplification of DNA with a thermostable DNA polymerase.Science, 239: 487-491.

Stovic, z.; Torres, A. M. and Cubero, J. I. (1996). Genetic mapping of new morphological, isozyme and RAPD markers in Vicia faba L. Using trisomic. Theor.Appl.Genet., 93: 1130-1138.

Torres, A.M.; Weeden, N. F. and Martin, A. (1993). Linkage among isozyme, RFLP and RAPD markers in Vicia faba. Theor. App.Geneties, 85: 937945.

Van de ven, W.T.G.; Duncan, N.; Ramsay, G.; Phillips, M.; Pwell, W. and Waugh, R. (1993). Taxonomic relationships between V.faba and its relatives based on nuclear and mitochondrial RFLPs and PCR analysis. Theor. Appl.Geneties, $86: 71-80$.

Williams, J. G. K; Kubelik, A. R.; Livak, K. J.; Rafalski, J. A. and Tingey, S. V. (1990). DNA polymorphism amplified by arbitrary primers are useful as genetic markers. Nucleic Acid Res., 18:6531-6535. 


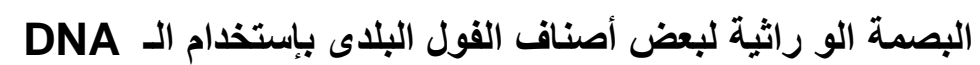

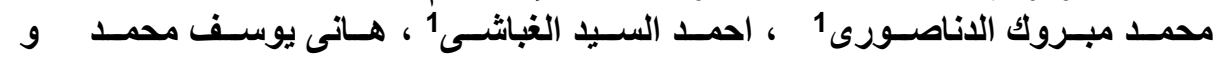
رحاب تودى بحيرى 1- قـم الكيمياء الحيويةـ كلية الزراعةـ جامعة الأزهر.

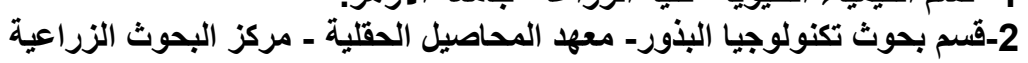

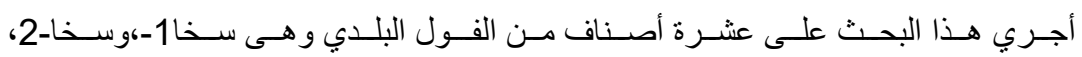

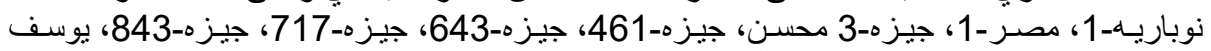

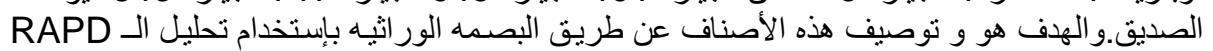

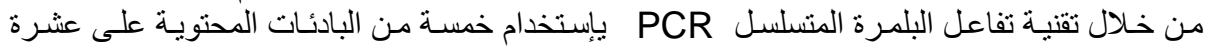
قو اعد عشو ائية التنتابع تراوح عدد الحزم التى تم الحصول عليها لكل بادئ من واحد (A 12) إلى 12 (B 10 (B 10 ).

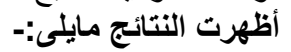

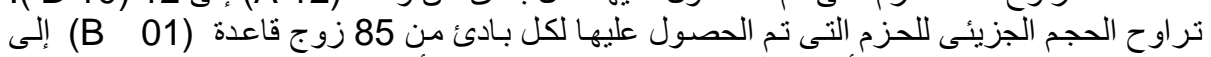

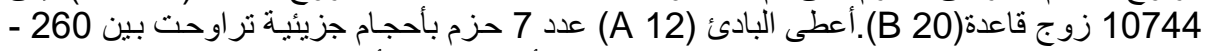

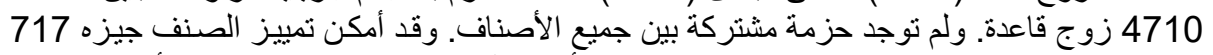
بوجود حزمة مميزة بحجم جزيئي 1290 زونة زوجة قاعدة.

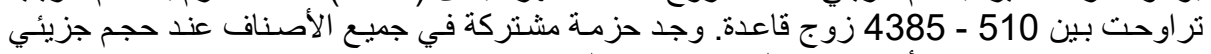

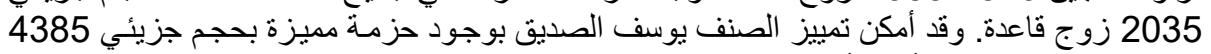

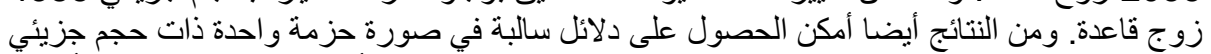

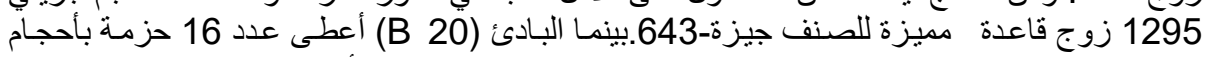

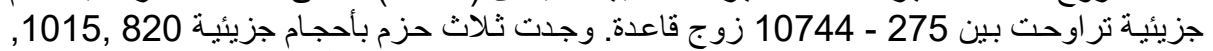

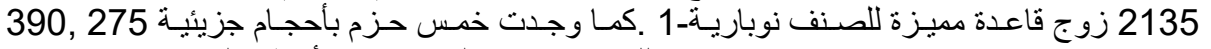
10744, 3360 1160,

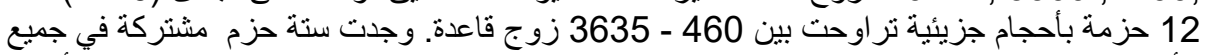
الأصناف عند حجم جزيئي 605, بئ بين 800 , 1265, 1440, 2695,

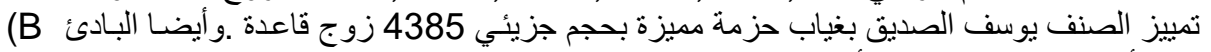

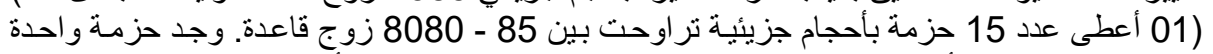

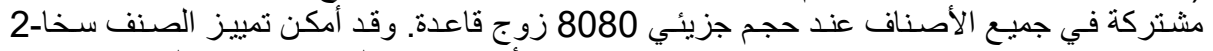

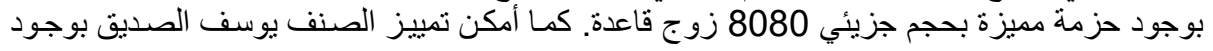
حزمتين مميزة بحجم جزيئي 5445 زوج قاعدة. 